\title{
Glycation impairs high-density lipoprotein function
}

\author{
C.C. Hedrick ${ }^{1}$, S. R. Thorpe ${ }^{2}$, M.-X.Fu' ${ }^{2}$ C.M.Harper, J. Yoo ${ }^{3}$, S.-M. Kim ${ }^{3}$, H. Wong ${ }^{4}$, A. L.Peters ${ }^{5}$ \\ ${ }^{1}$ Division of Cardiology, University of California School of Medicine, Los Angeles, California, USA \\ ${ }^{2}$ Department of Chemistry and Biochemistry, University of South Carolina, Columbia, South Carolina, USA \\ ${ }^{3}$ Undergraduate Student Research Program, University of California, Los Angeles, California, USA \\ ${ }^{4}$ Veterans Administration Wadsworth Medical Center, University of California, Los Angeles, California, USA \\ ${ }^{5}$ Division of Endocrinology, University of California School of Medicine, Los Angeles, California, USA
}

\section{Abstract}

Aims/hypothesis. To examine the effects of incubation of high-density lipoprotein (HDL) under hyperglycaemic conditions on several functions of HDL in vitro.

Methods. Human HDL (5 mg protein) was incubated for 1 week at $37^{\circ} \mathrm{C}$ in the presence or absence of $25 \mathrm{mmol} / 1$ glucose. Additional samples of human HDL were incubated in butylated hydroxytoluene to control for oxidation.

Results. High-density lipoprotein incubated for 1 week in $25 \mathrm{mmol} / \mathrm{l}$ glucose had significant increases in the glycation product, fructoselysine and in the advanced glycation end product, $N^{\varepsilon}$-(carboxymethyl)lysine. High-density lipoprotein apolipoprotein AI and AII concentrations were not altered but glycated HDL had a $65 \%$ reduction in paraoxonase enzymatic activity. Glycated HDL did not inhibit monocyte adhesion to human aortic endothelial cells in response to oxidised low-density lipoprotein in vitro (43 \pm 4 monocytes bound vs $21 \pm 2$ monocytes for control HDL, $p<0.0001)$. Hepatic lipase-mediated non-esterified fatty acid release from HDL lipids was enhanced in glycated HDL compared with control HDL ( $25 \pm 1$ vs $16 \pm 1 \mathrm{nmol}$ non-esterified fatty acid hydrolysed/min, respectively, $p<0.0001)$. Direct glycation of purified paraoxonase protein by incubation in $25 \mathrm{mmol} / \mathrm{l}$ glucose caused a $40 \%$ reduction in enzymatic activity. This glycated paraoxonase did not inhibit monocyte adhesion to human aortic endothelial cells in vitro $(68 \pm 3$ monocytes vs $49 \pm 2$ monocytes bound for control paraoxonase, respectively, $p<0.001)$. We also measured a $40 \%$ reduction in paraoxonase activity in patients with Type II (non-insulin-dependent) diabetes mellitus and documented coronary artery disease compared with nondiabetic subjects, $p<0.0001$.

Conclusions/interpretation. Alterations in function of HDL caused by exposure to hyperglycaemic conditions could contribute to the accelerated atherosclerosis observed in Type II diabetes. [Diabetologia (2000) 43: 312-320]

Keywords Apolipoprotein AI, apolipoprotein AII, hepatic lipase, high-density lipoprotein, paraoxonase.
Received: 16 June 1999 and in final revised form: 18 October 1999

Corresponding author: C. C. Hedrick, PhD, UCLA Division of Cardiology, 47-123 CHS, 10833 LeConte Avenue, Los Angeles, CA 90095-1679, USA

Abbreviations: AGE, Advanced glycation end product; Apo, apolipoprotein; BHT, butylated hydroxytoluene, 2(6)-di-tertbutyl-p-cresol; CAD, coronary artery disease; CML, $N^{\varepsilon}$-(carboxymethyl)-lysine; MM-LDL, minimally modified low-density lipoprotein; PON, serum paraoxonase; TBARS, thiobarbituric reactive substances; HAEC, human aortic endothelial cells; FPLC, fast protein liquid chromatography; UCLA, University of California, Los Angeles.
High-density lipoproteins (HDL) are a heterogenous collection of particles which circulate in blood and serve several protective functions, including accepting lipids produced by hydrolysis of triglyceride-rich lipoproteins [1]. High-density lipoprotein concentrations are inversely related to incidence of coronary artery disease (CAD) in humans [2]. They can protect against CAD by removing cholesterol from peripheral tissues and transporting it to liver, a process termed reverse cholesterol transport. In addition, HDL can protect against CAD by preventing lowdensity lipoprotein (LDL) oxidation within the artery 
wall or by inactivating LDL oxidation products through the actions of its associated enzyme, paraoxonase (PON) [3].

Paraoxonase is an HDL-associated ester hydrolase that is important in prevention of LDL oxidation. It has been reported to inhibit copper-induced lipid peroxide generation in LDL [4], and been shown to inhibit the biological activity of mildly oxidised LDL in vitro [5]. In humans, a polymorphism exists in PON at amino acid position 191 which generates two allozymes, A and B, which differ in only a single amino acid [6]. The $\mathrm{B}$ form has been associated with lower PON activity and was linked to CAD risk in a group with Type II (non-insulin-dependent) diabetes mellitus patients [7]. These data suggest that HDLassociated PON activity could be important in modulating atherosclerosis development, especially in patients with diabetes.

Hepatic lipase is a liver enzyme involved in hydrolysis of fatty acids from lipoprotein phospholipids and triglycerides [8]. The enzyme is mainly involved in the processing and recycling of large HDL $\left(\mathrm{HDL}_{2}\right)$ into smaller HDL $\left(\mathrm{HDL}_{3}\right)$. Hepatic lipase enzyme activities in human postheparin plasma have been shown to be inversely correlated with plasma $\mathrm{HDL}_{2}$ concentrations [9] and studies have shown that the composition of HDL affects its ability to react with hepatic lipase $[10,11]$. Patients with Type II diabetes have been shown to have decreased $\mathrm{HDL}_{2}$ concentrations, and increases in plasma non-esterified fatty acids (NEFA) levels [12-14]. In some of these studies, but not all, hepatic lipase activity was found to be increased [14].

Patients with Type II diabetes have an increased incidence of CAD [15], although the pathogenic mechanisms are incompletely understood. One possibility is that hyperglycaemia accelerates atherogenesis in diabetic patients by increasing lipoprotein oxidation [16, 17]. Further, modestly increased concentrations of glucose have been shown to increase monocyte adherence to human aortic endothelial cells [18], a key early event in atherogenesis. Another consideration is the non-enzymatic formation of advanced glycation end products (AGE) through longterm exposure of proteins and lipids to glucose. Advanced glycation end products are increased in tissue proteins of diabetic subjects and are correlated with the severity of diabetic complications [19-21]. In patients with diabetes, apolipoprotein glycation correlates positively with common indices of glycaemic control, including $\mathrm{HbA}_{1 \mathrm{c}}$, although AGEs were not measured in these studies [22]. Glycation or glycoxidation of enzymes or both and apolipoproteins involved in HDL metabolism could cause abnormal HDL function and contribute to the acceleration of atherogenesis in diabetic people [23-25].

In this study, we hypothesised that increased glycation of HDL would alter its function and anti-athero- genic properties. To examine how HDL metabolism could be altered by glycation, we examined the affinity of glycated HDL for hepatic lipase in vitro. We also examined some of the anti-atherogenic properties of HDL which could be altered by glycation, namely, PON activity and prevention of monocyte adhesion to endothelium, a key initial event in atherogenesis.

\section{Subjects and methods}

Modification of HDL with glucose. Fasted blood from five normal healthy human donors with no history of either CAD or diabetes was collected into heparin $(4 \mu \mathrm{l} / \mathrm{ml}$ blood $)$ and HDL was isolated by density gradient ultracentrifugation as described [26]. To create glycated HDL, fresh human HDL ( $5 \mathrm{mg}$ protein) was incubated with $25 \mathrm{mmol} / \mathrm{l}$ glucose in phosphate-buffered saline (PBS) under sterile conditions for 1 week at $37^{\circ} \mathrm{C}$ (referred to as G HDL). High-density lipoprotein $\left(5 \mathrm{mg}\right.$ protein) were incubated in PBS at $37^{\circ} \mathrm{C}$ in the absence of glucose under the same conditions (referred to as PBS HDL). Additional samples of HDL (5 mg protein) were incubated under the same conditions with $20 \mu \mathrm{mol} / \mathrm{l}$ butylated hydroxytoluene (BHT) in the absence (referred to as PBS/ $\mathrm{BHT}$ ) or presence of $25 \mathrm{mmol} / \mathrm{l}$ glucose (referred to as $\mathrm{G} /$ BHT) to be used as controls for oxidation. Starting, unincubated HDL from the same donors (5 $\mathrm{mg}$ protein each) were stored at $4{ }^{\circ} \mathrm{C}$ throughout the experiment to be used as a control (referred to as CTR HDL).

Modification of PON with glucose. Purified isolated PON protein, $100 \mu \mathrm{g}$, (kindly provided by Dr. B. LaDu, University of Michigan) was incubated in PBS either with (referred to as $\mathrm{PON}+\mathrm{G}$ ) or without (referred to as PON + PBS) $25 \mathrm{mmol} / \mathrm{l}$ glucose at $37^{\circ} \mathrm{C}$ for 1 week. Samples were stored at $4^{\circ} \mathrm{C}$ after incubation and assayed within $24 \mathrm{~h}$ for enzymatic activity as described below.

Determination of PON activity. Both the arylesterase and paraoxonase enzymatic activities of human serum PON were measured in either the HDL preparations or in the purified PON preparations [27]. Arylesterase activity of either HDL preparations or purified PON protein was measured by the addition of each HDL preparation $(100 \mu \mathrm{g}$ protein) or each purified PON preparation ( $10 \mu \mathrm{g}$ protein) to a solution of $1 \mathrm{mmol} / \mathrm{l}$ phenylacetate in $20 \mathrm{mmol} / \mathrm{l}$ TRIS- $\mathrm{HCl}, \mathrm{pH}$ 8.0. The increase in absorbance at $270 \mathrm{~nm}$ was recorded over 2 min. Blanks of substrate without enzyme were included to correct for the spontaneous hydrolysis of phenylacetate, which generally accounted for less than $5 \%$ of the substrate. Enzymatic activity was calculated from the molar extinction coefficient $1310 \cdot \mathrm{Mol}^{-1} \cdot \mathrm{cm}^{-1}$.

Paraoxonase activity was measured using paraoxon as the substrate and measuring the increase in absorbance at $405 \mathrm{~nm}$ due to formation of 4-nitrophenol. Enzyme activity was measured in $50 \mathrm{mmol} / 1$ glycine $/ 1 \mathrm{mmol} / 1 \mathrm{CaCl}_{2} / 2.0 \mathrm{~mol} / 1 \mathrm{NaCl}$ at $\mathrm{pH} 10.5$ as described [27]. The amount of 4-nitrophenol generated was calculated from the molar extinction coefficient $18290 \cdot \mathrm{Mol}^{-1} \cdot \mathrm{cm}^{-1}$.

Study cohort and blood collection. After signing a written consent approved by the University of California Human Subjects committee, subjects undergoing coronary angiography at the University of California, Los Angeles (UCLA) donated a sample of fasted whole blood which was collected into heparinised 
Table 1. Serum paraoxonase activity in patients with Type II diabetes and CAD

\begin{tabular}{|c|c|c|c|c|c|c|}
\hline Group & $\begin{array}{l}\text { Total Cholesterol } \\
(\mathrm{mmol} / \mathrm{l})\end{array}$ & $\begin{array}{l}\mathrm{HDL}-\mathrm{C} \\
(\mathrm{mmol} / \mathrm{l})\end{array}$ & $\begin{array}{l}\text { Triglycerides } \\
(\mathrm{mg} / \mathrm{dl})\end{array}$ & $\begin{array}{l}\text { Fasting Glucose } \\
(\mathrm{mmol} / \mathrm{l})\end{array}$ & $\begin{array}{l}\text { PON Activity } \\
(\mathrm{U} / \mathrm{ml})\end{array}$ & $\begin{array}{l}\mathrm{PON} / \mathrm{HDL}- \\
\mathrm{C} \text { ratio }\end{array}$ \\
\hline Diabetics + CAD $(n=10)$ & $5.02 \pm 0.36$ & $0.83 \pm 0.08$ & $2.59 \pm 0.64^{\mathrm{a}}$ & $9.4 \pm 0.9^{\mathrm{a}}$ & $67 \pm 7^{\mathrm{a}}$ & $1.9 \pm 0.3^{\mathrm{a}}$ \\
\hline Nondiabetics + CAD $(n=12)$ & $4.72 \pm 0.39$ & $1.06 \pm 0.10$ & $1.34 \pm 0.20$ & $5.6 \pm 0.2$ & $111 \pm 14$ & $3.1 \pm 0.5$ \\
\hline
\end{tabular}

a Significantly different from nondiabetic group by Student's $t$ test, $p<0.05$. PON/HDL-C ratio was calculated using PON activity for each patient

tubes in the absence of ethylenediaminetetraacetic acid (EDTA). Plasma was obtained by centrifuging the blood at $2500 \mathrm{rpm}$ for $10 \mathrm{~min}$ and then plasma was stored at $4{ }^{\circ} \mathrm{C}$; PON activity was determined within $24 \mathrm{~h}$ of collection. Blood was drawn from two groups of patients with documented CAD. One group of patients had documented Type II diabetes (see Table 1 for fasting plasma glucose values), whereas the other group had normal fasting blood glucose values and no history of diabetes. The patients studied were men, non-smokers and none were taking lipid-lowering drugs. None had a history of hypertension. The mean age of the diabetic group was $60 \pm 3$ years and $63 \pm 4$ years for the non-diabetic group.

High-density lipoprotein characterisation. High-density lipoprotein size was analysed using fast protein liquid chromatography (FPLC). For FPLC analysis, unincubated, starting HDL $(150 \mu \mathrm{g}$ protein $)$ or each HDL sample $(150 \mu \mathrm{g}$ protein $)$ were sized using two Superose 6 columns connected in series (Amersham Pharmacia Biotech, Piscataway, N.J., USA) [28]. Fractions of $0.5 \mathrm{ml}$ were collected at a rate of $0.5 \mathrm{ml} / \mathrm{min}$ in $0.9 \%$ sodium chloride. The particle sizes of HDL were determined by comparing elution volumes with molecular weight standards (Amersham Pharmacia Biotech). After incubation in the presence or absence of glucose, HDL preparations $(15 \mu \mathrm{g}$ protein) were analysed by sodium dodecyl sulphate polyacrylamide gel electrophoresis (SDS-PAGE) under reducing conditions using 4-20\% TRIS-glycine gels (Novex, San Diego, Calif., USA) at $45 \mathrm{~mA}$ for $1.5 \mathrm{~h}$. Gels were then stained with Coomassie blue to make apolipoprotein AI and apolipoprotein AII visible.

Chemical analyses of HDL. Measurement of glycation (fructoselysine) and carboxymethylation ( $N^{\varepsilon}$-(carboxymethyl)-lysine, CML) of HDL preparations was carried out by isotope dilution mass spectrometry [29]. Fructoselysine was measured in unreduced protein and CML was measured in HDL which was first reduced with $100 \mathrm{mmol} / \mathrm{l} \mathrm{NaBH}$. Analyses of both reduced and unreduced HDL were carried out after protein delipidation using two sequential overnight extractions with ethanol:ether (3:1). Heavy labelled internal standards were added to the residual protein, which was then hydrolysed in $6 \mathrm{~N} \mathrm{HCl}$ at $110^{\circ} \mathrm{C}$ for $24 \mathrm{~h}$; after drying the hydrolysate was passed over a $1 \mathrm{ml} \mathrm{C} 18$ column to remove brown impurities and amino acids were then derivatised as their trifluoroacetyl methyl esters (TFAME) for analysis by selective ion monitoring gas chromatography - mass spectrometry [29]. Malondialdehyde concentrations [thiobarbituric acid-reactive substances (TBARS)] in HDL were measured using the thiobarbituric acid assay as described [30]. Conjugated diene concentrations in HDL preparations were determined by measuring their absorbance at $234 \mathrm{~nm}$ [31].

Hepatic lipase assay. To test the ability of glycated HDL to interact with hepatic lipase, the following assay in vitro was done: unincubated, starting control HDL ( $40 \mu \mathrm{g}$ protein) or HDL incubated in either PBS or $25 \mathrm{mmol} / \mathrm{l}$ glucose for 1 week (40 $\mu \mathrm{g}$ protein each) were incubated with $1.5 \mu \mathrm{g}$ of recombinant human hepatic lipase for 1,2 and $4 \mathrm{~h}$ at $28^{\circ} \mathrm{C}$ in $100 \mathrm{mmol} / \mathrm{l}$ TRIS-HCl pH 8.0 containing $4 \%$ (w/v) bovine serum albumin (BSA). An additional $40 \mu \mathrm{g}$ protein of each HDL preparation was also added to $1.5 \mu \mathrm{g}$ of recombinant hepatic lipase and immediately stored at $4{ }^{\circ} \mathrm{C}$ to use as time 0 controls. The hydrolysis and release of non-esterified fatty acids from triglycerides and phospholipids in HDL was quantified using a colorimetric assay as described [32].

Monocyte adhesion assay. Human aortic endothelial cells (HAEC) were isolated from aortic tissue obtained from the UCLA transplant programme in accordance with UCLA guidelines and grown to confluence in medium M199 supplemented with $10 \%$ fetal bovine serum (FBS) with endothelial cell growth supplement (ECGS) and heparin. Minimally modified LDL (MM-LDL, $250 \mu \mathrm{g}$ protein/ml, prepared as described [33]) and $150 \mu \mathrm{g}$ protein of unincubated, starting HDL or $150 \mu \mathrm{g}$ protein of $\mathrm{HDL}$ incubated in either PBS or $25 \mathrm{mmol} / \mathrm{l}$ glucose for 1 week were added together in M199 + 5\% FBS to the HAEC monolayer and incubated at $37^{\circ} \mathrm{C}$ for $4 \mathrm{~h}$. Adhesion assays were then done as described [34]. Briefly, cells were rinsed twice with serum-free medium and $1 \times 10^{6}$ monocytes were incubated with the HAEC for $15 \mathrm{~min}$ at $37^{\circ} \mathrm{C}$. Non-adherent monocytes were rinsed away with PBS and cells were fixed with $1 \%$ glutaraldehyde. The number of attached monocytes were counted using a phase contrast microscope under $100 \times$ magnification. Blood monocytes were obtained from a large pool of healthy donors by modification of the Recalde method [35]. Studies of monocyte adhesion were also conducted after treatment of MM-LDL with glycated and control PON. For these experiments, $10 \mu \mathrm{g}$ of either glycated or control PON protein were incubated with $125 \mu \mathrm{g}$ protein/ml MM-LDL in PBS overnight at $37^{\circ} \mathrm{C}$. The PON-MM-LDL mixture was then incubated with a confluent monolayer of HAEC for $4 \mathrm{~h}$ at $37^{\circ} \mathrm{C}$ and monocyte adhesion assays were then done as described above.

Statistical analysis. All data are represented as means \pm SEM. Statistical analysis was done using the Student's $t$ test. When multiple comparisons were evaluated, analysis of variance (ANOVA) was carried out. For the ANOVA, a Fisher exact test was used to determine $95 \%$ confidence intervals. Values were considered to be significant at $p$ less then 0.05 .

\section{Results}

High-density lipoprotein incubated in glucose contained AGE and lipid oxidation products. High density lipoprotein incubated in $25 \mathrm{mmol} / \mathrm{l}$ glucose in vitro for 1 week (G HDL) showed an approximate fourfold increase in glycation, measured as the Amadori product, fructoselysine (Table 2 ). There was a more modest increase in the content of the AGE, CML, 
Table 2. Concentrations of fructoselysine and CML in HDL

\begin{tabular}{lll}
\hline Group & $\begin{array}{l}\text { Fructoselysine } \\
(\mathrm{mmol} / \mathrm{mol} \text { lysine })\end{array}$ & $\begin{array}{l}N^{\epsilon} \text {-(carboxymethyl)-lysine } \\
(\mathrm{CML})(\mathrm{mmol} / \mathrm{mol} \text { lysine })\end{array}$ \\
\hline CTR HDL $^{\mathrm{a}}$ & $0.64 \pm 0.08^{\mathrm{b}}$ & $0.08 \pm 0.03^{\mathrm{d}}$ \\
PBS HDL & $0.98 \pm 0.12^{\mathrm{b}}$ & $0.10 \pm 0.02^{\mathrm{d}}$ \\
G HDL & $2.93 \pm 0.34^{\mathrm{c}}$ & $0.16 \pm 0.02^{\mathrm{e}}$
\end{tabular}

Data represent the means \pm SEM of four experiments, each using a different HDL preparation.

${ }^{\text {a }}$ Unincubated, starting HDL from same donors

$\mathrm{b}, \mathrm{c}$ Values for fructoselysine are significantly different by ANOVA, $p<0.0002$

$\mathrm{d}$, e Values for CML are significantly different by ANOVA, $p<0.02$

which rose about $70 \%$ during the same period. There was no statistically significant change in either fructoselysine or CML in HDL incubated in the absence of glucose (PBS HDL).

Because CML can be formed from oxidation of lipids as well as from fructoselysine [36] we used the TBARS assay [30] to evaluate whether the presence of glucose would cause statistically significant oxidation of lipids in HDL. Glycated (G HDL) and PBSincubated HDL (PBS HDL) both showed increased concentrations of malondialdehyde measured as TBARS over the week-long incubation period (Table 3). Concentrations of TBARS were higher in $G$ HDL than in PBS HDL $(34.67 \pm 0.33$ vs $22.75 \pm$ $0.25 \mu \mathrm{mol} / \mu \mathrm{g}$ protein, respectively, $p<0.001)$. Samples of HDL which were incubated in BHT in the presence $(\mathrm{G} / \mathrm{BHT})$ or absence of $25 \mathrm{mmol} / \mathrm{l}$ glucose (PBS/BHT) had lower concentrations of TBARS than their non-BHT counterparts; samples treated with BHT did, however, have higher concentrations of TBARS than did control, unincubated starting HDL (CTR HDL), $p<0.01$.

We also measured conjugated dienes in the HDL preparations (Table 3), and found small but significant $(p<0.02)$ increases in conjugated dienes over the 1-week incubation period. Concentrations of conjugated dienes in control, unincubated HDL (CTR HDL) were $0.05 \pm 0.001$ AU [absorbance (O.D.) at $234 \mathrm{~nm}$ ], while concentrations in G HDL were twofold higher $(0.11 \pm 0.01 \mathrm{AU}), p<0.02$. Conjugated diene concentrations in PBS HDL were similar to those in CTR HDL. Samples of HDL which were incubated in BHT in the presence (G/BHT) or absence (PBS/BHT) of $25 \mathrm{mmol} / \mathrm{l}$ glucose had lower concentrations of conjugated dienes than their non-BHT counterparts, yet were not statistically significantly different from control HDL (CTR HDL). Taken together, these data indicate that the HDL preparations incubated in $25 \mathrm{mmol} / \mathrm{l}$ glucose accumulated glycation products, AGE and lipid oxidation products. Also that HDL preparations incubated in PBS (PBS HDL) accumulated some lipid oxidation products but no glycation or AGE products.
Table 3. Effect of incubation of HDL in glucose on formation of conjugated dienes and TBARS

\begin{tabular}{llc}
\hline Group & $\begin{array}{l}\text { Conjugated Dienes } \\
\left(\mathrm{OD}_{234}\right)\end{array}$ & $\begin{array}{l}\text { TBARS }(\mu \mathrm{mol} / \mu \mathrm{g} \\
\text { protein })\end{array}$ \\
\hline CTR HDL & $0.05 \pm 0.001^{\mathrm{x}}$ & $6.52 \pm 0.48^{\mathrm{a}}$ \\
PBS HDL & $0.08 \pm 0.01^{\mathrm{x}}$ & $22.75 \pm 0.25^{\mathrm{b}}$ \\
PBS/BHT & $0.06 \pm 0.02^{\mathrm{x}}$ & $12.09 \pm 0.91^{\mathrm{c}}$ \\
G HDL & $0.11 \pm 0.01^{\mathrm{y}}$ & $34.67 \pm 0.33^{\mathrm{d}}$ \\
G/BHT & $0.09 \pm 0.01^{\mathrm{x}, \mathrm{y}}$ & $11.42 \pm 0.58^{\mathrm{c}}$ \\
\hline
\end{tabular}

Data represent the means \pm SEM of five experiments, each using a different HDL preparation.

HDL from five subjects $(1 \mathrm{mg} / \mathrm{ml})$ was incubated at $37^{\circ} \mathrm{C}$ for 1 week as described in Methods. Samples were analysed for development of conjugated dienes by measuring absorbance at $234 \mathrm{~nm}$ or for TBARS as described in Methods.

Values for conjugated dienes with different letters ( $x$ and $y$ ) are significantly different for each group of HDL by ANOVA, $p<0.02$.

Values for TBARS with different letters $(a, b, c$, and $d)$ are significantly different for each group of HDL by ANOVA, $p<0.01$

Size of HDL altered by glycation/glycoxidation. To examine whether glycation caused alterations in HDL apolipoproteins, apolipoproteins AI and AII in glycated HDL, preparations were examined by SDS-PAGE. Both glycated HDL and control, unincubated HDL seemed to have similar concentrations of both apolipoproteins AI and AII, the major apolipoproteins found on HDL (Fig. 1). High-density lipoprotein incubated for 1 week in either PBS (Lane 5 ) or in $25 \mathrm{mmol} / \mathrm{l}$ glucose (Lane 4) showed decreased apoAI migration compared with unincubated control HDL (Lane 1) or compared with HDL incubated for 1 week in PBS/BHT (Lane 2) or 1 week in $25 \mathrm{mmol} / \mathrm{l}$ glucose + BHT (G/BHT) (Lane 3). The slower migration observed for HDL samples which were not treated with BHT was, however, independent of glucose treatment. We examined HDL size using FPLC as shown in Fig. 2. We found G HDL (approximate diameter of $11.7 \mathrm{~nm}$ ) were larger in size than native, unincubated, starting HDL (approximate diameter of $10.1 \mathrm{~nm}$ ). This increase in size did not, however, appear to be glucose-dependent because both G HDL and PBS HDL were similar in size.

Glycated HDL as a substrate for hepatic lipase. To examine the ability of glycated HDL to interact with hepatic lipase, we compared the release of non-esterified fatty acids from triglycerides and phospholipids of glycated and control HDL preparations by hepatic lipase (Fig. 3). At $4 \mathrm{~h}$, the release of fatty acids from glycated HDL (G HDL) was considerably increased, to $150 \%$ of control (CTR)HDL $(25 \pm 1$ nmol NEFA vs $16 \pm 1$ nmol NEFA, respectively, $p<0.001)$. The release of NEFA from G HDL was also higher than from PBS HDL, $p<0.003$. The release of NEFA from PBS HDL was slightly greater than from CTR 


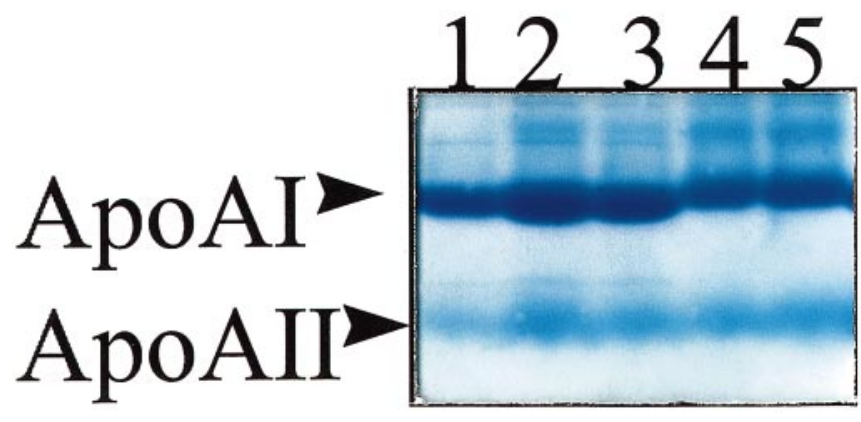

Fig. 1. Incubation of HDL in $25 \mathrm{mmol} / 1$ glucose for 1 week at $37^{\circ} \mathrm{C}$ results in slower migration of apoAI or apoAII. HDL protein $(15 \mu \mathrm{g})$ was analysed by $4-20 \%$ SDS-PAGE and visualised using Coomassie blue. Lane 1: starting, unincubated HDL; Lane 2: PBS/BHT HDL; Lane 3: G/BHT HDL; Lane 4: HDL incubated in PBS + $25 \mathrm{mmol} / 1$ glucose for 1 week $(\mathrm{G}$ HDL); Lane 5: HDL incubated in PBS for 1 week (PBS HDL). The concentrations of apoAI and apoAII appeared to be similar for all groups of HDL and there was no apparent degradation of the apolipoproteins as a result of the 1 week of incubation. The migration of apoAI on HDL was slower, independent of the presence of glucose

HDL (19 \pm 1 versus $16 \pm 1$ nmol NEFA, respectively, $p<0.01)$.

Glycated $H D L$ did not prevent $M M-L D L$-induced monocyte adhesion to HAEC. A biological assay which is routinely used to determine whether LDL is oxidised is to examine monocyte adhesion to HAEC after incubation with LDL. As LDL becomes oxidised, it induces monocyte-specific adhesion molecules resulting in monocyte adherence to endothelium [37]. High-density lipoprotein has been shown to inactivate biologically active lipid intermediates in MM-LDL reducing monocyte adhesion to HAEC in

Fig. 2 A, B. Incubation of HDL with or without glucose increases particle size. High-density lipoprotein pooled from three donors was analysed by FPLC using two Superose 6 columns in series. A. Profiles represent total cholesterol in each fraction and are for $150 \mu \mathrm{g}$ unincubated HDL (O) or $150 \mu \mathrm{g}$ HDL incubated for 1 week in PBS (PBS HDL, $\Delta$ ) or in $25 \mathrm{mmol} / \mathrm{l}$ glucose (G HDL, $\boldsymbol{\square}$ ). B shows the particle diameter as a function of elution volume

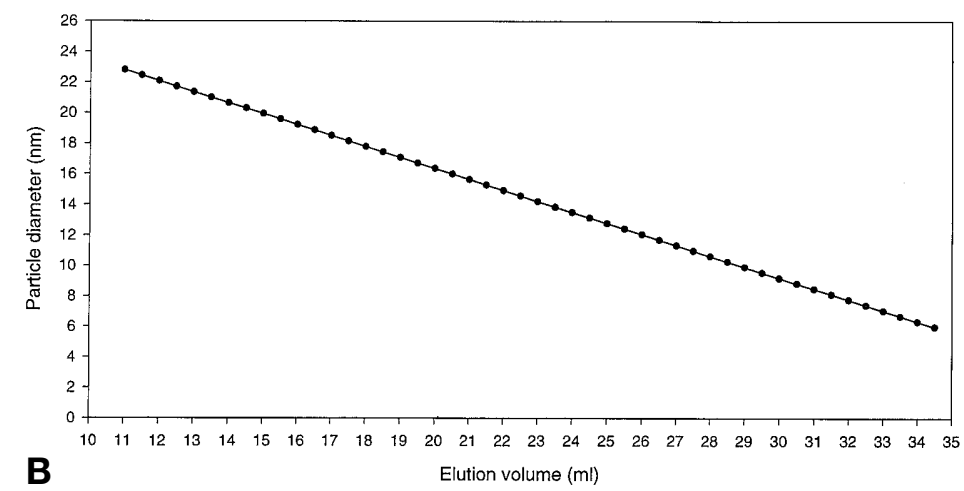

vitro [3]. Further, PON could inhibit this process through inactivation of LDL-derived oxidised lipids [5]. Control unincubated HDL (CTR HDL) blocked induction of monocyte adhesion to endothelial cells in response to MM-LDL, $(21 \pm 2$ vs $48 \pm 3$ cells/field, $p<0.0001$ ) (Fig.4). Glycated HDL (G HDL) did not, however, prevent induction of monocyte adhesion to endothelial cells, $43 \pm 4$ cells/field compared with $21 \pm 2$ cells/field for control HDL, $p<0.0001$. The ability of PBS HDL to prevent monocyte:endothelial interactions was, however, also decreased although G HDL was less effective than oxidised PBS HDL, $43 \pm 4$ compared with $34 \pm 3$ monocytes/field, $p<0.01$. The activity of PON was also reduced in $\mathrm{G}$ HDL and PBS HDL compared with CTR HDL, $38 \pm 3 \mathrm{U} / \mathrm{ml}$ and $65 \pm 5 \mathrm{U} / \mathrm{ml}$, compared with $105 \pm 4$ $\mathrm{U} / \mathrm{ml}$, respectively, $p<0.001$ (data not shown). We found G HDL was statistically significantly lower than PBS HDL, suggesting that glycation has a more severe effect on PON activity than does oxidation in these experiments. Taken together, these results indi-

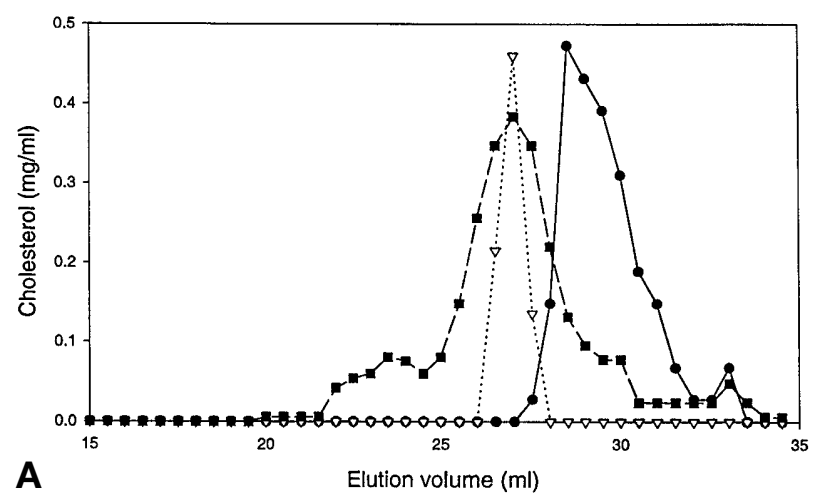

B

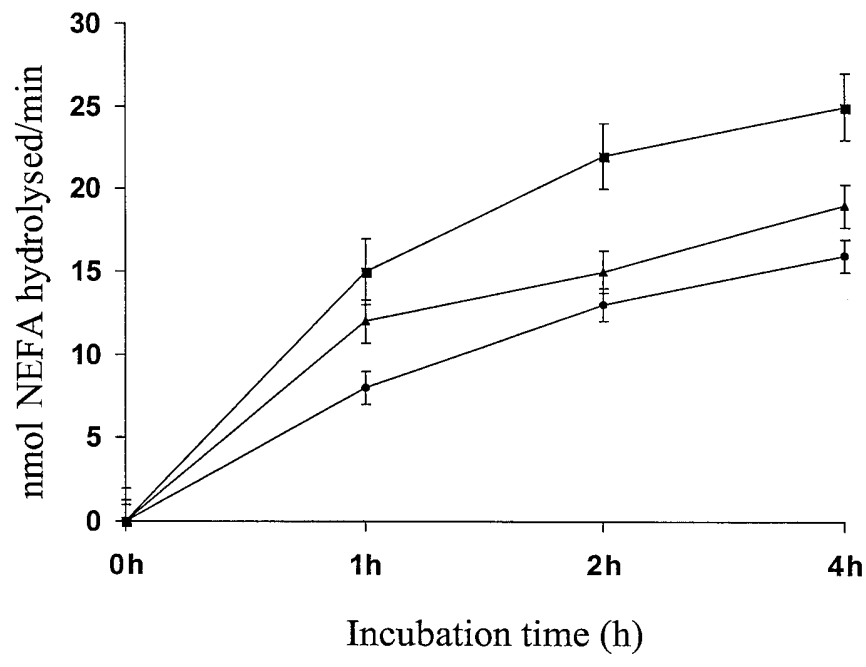

Fig. 3. Glycation of HDL alters its interaction with hepatic li-
pase. As described in Methods $40 \mu \mathrm{g}$ of HDL were incubated with hepatic lipase. The hydrolysis of NEFA from HDL by hePBS HDL $(\boldsymbol{\Delta})$ and G HDL $(\boldsymbol{\square})$. Data represents the means \pm SEM of HDL from three donor preparations

Elution volume $(\mathrm{ml})$ 


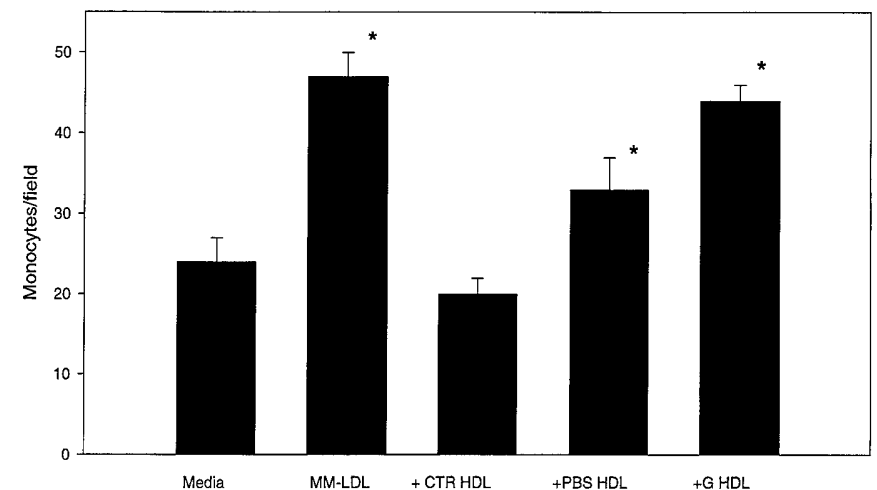

Fig.4. Incubation of HDL with glucose impairs its ability to detoxify MM-LDL. MM-LDL $(250 \mu \mathrm{g})$ was incubated for $4 \mathrm{~h}$ at $37^{\circ} \mathrm{C}$ with either HDL incubated in PBS only (+ PBS HDL) or incubated in $25 \mathrm{mmol} / 1$ glucose $(+G H D L)$. The MM-LDL was then tested for its ability to induce endothelial cells to produce monocyte chemoattractants and bind monocytes. Standard errors for the mean of three experiments are shown. Media: media only; $M M-L D L$ : MM-LDL incubated in media only in the absence of any HDL preparation as a positive control; + CTR HDL: $250 \mu \mathrm{g} / \mathrm{ml}$ MM-LDL + $150 \mu \mathrm{g}$ unincubated, starting HDL. An asterisk (*) represents significantly different values from CTR HDL, $p<0.01$. Groups that are significantly higher than CTR HDL by ANOVA, $p<0.001$. Data are means \pm SEM for three individual donors

cate that both glycated as well as oxidised HDL have a decreased ability to prevent MM-LDL-induced monocyte adhesion to endothelial cells and that this could be mediated, at least in part, by a reduction in PON activity.

Glycation of PON decreases enzyme activity. To examine further the effects of glycation and oxidation on PON activity, we measured whether direct glycation or oxidation of PON protein resulted in diminished PON enzymatic activity. Incubation of purified PON protein for 1 week in PBS (PON + PBS) decreased paraoxonase activity from $102 \pm 2 \mathrm{U} / \mathrm{ml}$ to $84 \pm 9 \mathrm{U} / \mathrm{ml}, p=0.06$ (Fig. 5 ). This $18 \%$ reduction in enzyme activity could reflect protein denaturation/ oxidation during the incubation time. Over the same period of incubation, PON protein incubated for 1 week in $25 \mathrm{mmol} / \mathrm{l}$ glucose $(\mathrm{PON}+\mathrm{G})$ had, however, a $40 \%$ reduction in activity, down to $62 \pm 9 \mathrm{U} / \mathrm{ml}$, $p<0.03$ (Fig. 5). These data suggest that glycation of PON protein has a great effect on its activity.

Glycated PON does not prevent monocyte adhesion to endothelial cells. As shown in Figure 6, MM-LDL stimulated monocyte adhesion to HAEC in vitro and control PON protein (CTR PON) inhibited induction of monocyte adhesion to HAEC in response to MM-LDL. Glycated PON (PON + G) was, however, less effective than control PON at reducing monocyte adhesion to HAEC, $68 \pm 3$ cells/field for glycated PON compared with $49 \pm 2$ cells/field for control

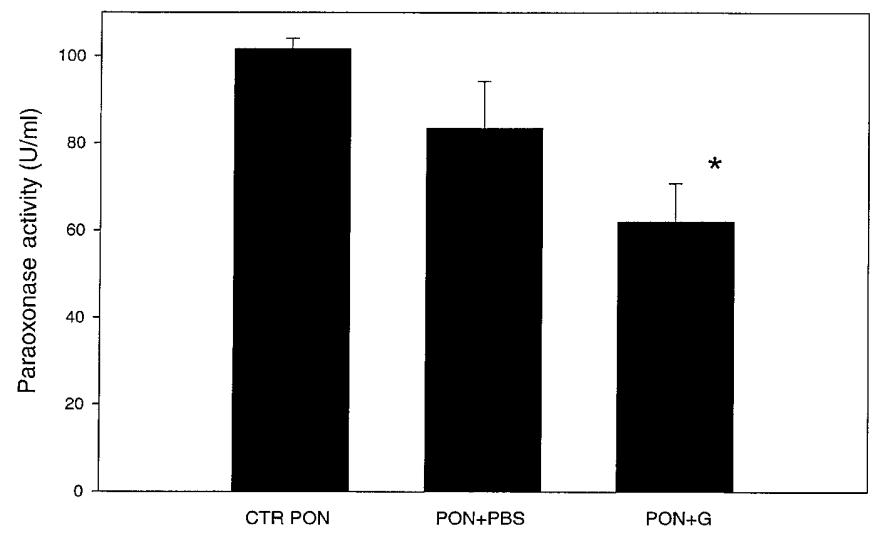

Fig. 5. Incubation of $\mathrm{PON}$ in $\mathrm{PBS}$ at $37^{\circ} \mathrm{C}$ in the presence of glucose accelerates the decline in enzyme activity. Purified PON enzyme $(10 \mu \mathrm{g})$ was incubated for 1 week in either PBS alone $(P O N+P B S)$ or in $\mathrm{PBS}+25 \mathrm{mmol} / \mathrm{l}$ glucose $(P O N+G)$ and then analysed for paraoxonase activity as described in Methods. CTR PON: $10 \mu \mathrm{g}$ unincubated, control PON. An asterisk (*) represents significantly different value from CTR PON, $p<0.03$. Data are means \pm SEM for three individual experiments

PON, $p<0.001$. Also, PON $+\mathrm{G}$ was less effective at reducing monocyte adhesion than $\mathrm{PON}$ protein incubated for 1 week in PBS (PON + PBS), $68 \pm 3$ cells/ field compared with $54 \pm 4$ cells/field respectively, $p<0.03$. These data suggest that PON activity is important in prevention of monocyte:endothelial interactions caused by mildly oxidised LDL and that glycated PON is unable to inhibit these interactions.

Patients with Type II diabetes have decreased PON activity. To examine PON activity in Type II diabetic patients in vivo, we measured PON activity in 10 men with Type II diabetes and documented CAD and in 12 non-diabetic men who also had documented CAD. Fasting blood glucose values were 1.7-fold higher in the diabetic compared with the non-diabetic subjects, $9.4 \pm 0.9 \mathrm{mmol} / \mathrm{l}$ compared with $5.6 \pm$ $0.2 \mathrm{mmol} / 1$, respectively, $p<0.001$ (Table 1 ). Total cholesterol concentrations were not different between the two groups. Concentrations of HDL-C were not different $(p>0.05)$ between the two groups, although there was a trend towards lower HDL-C in the diabetic group. Type II diabetic patients with CAD had an average $40 \%$ reduction in PON activity compared with the non-diabetic patients, $67 \pm 7 \mathrm{U} / \mathrm{ml}$ compared with $111 \pm 14 \mathrm{U} / \mathrm{ml}$, respectively, $p<0.0001$ (Table 1 ). The ratio of PON activity to HDL-C was also lower in the diabetic group, $p<0.05$. These data indicate that PON activity is lower in Type II diabetic patients than in non-diabetic subjects with CAD. 


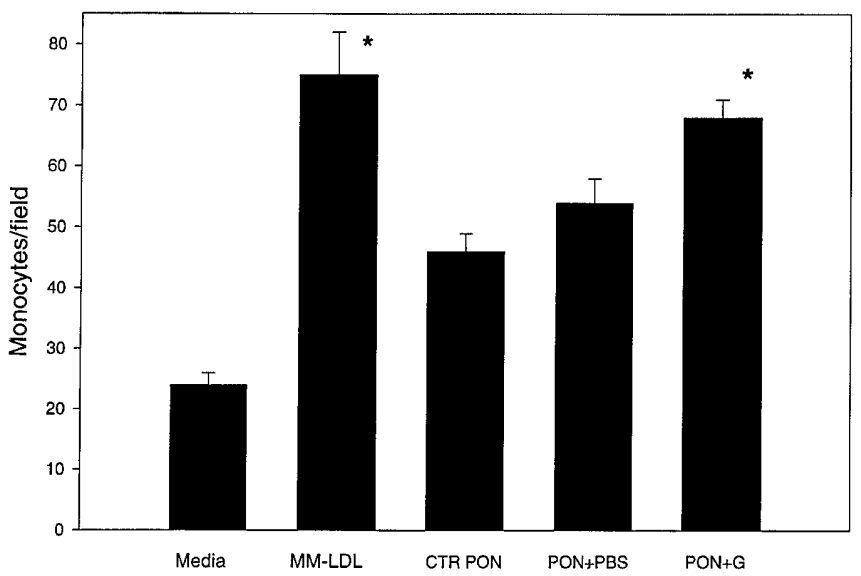

Fig. 6. Incubation of $\mathrm{PON}$ for 1 week in glucose impairs its ability to prevent MM-LDL induced monocyte adhesion to HAEC. MM-LDL $(125 \mu \mathrm{g} / \mathrm{ml})$ was incubated for $14 \mathrm{~h}$ at $37^{\circ} \mathrm{C}$ with PON $(10 \mu \mathrm{g})$ previously incubated for 1 week in either PBS alone $(P O N+P B S)$ or PBS $+25 \mathrm{mmol} / \mathrm{l}$ glucose $(P O N+G)$. The MM-LDL was then tested for its ability to induce endothelial cells to bind monocytes. Media: media only; $M M-L D L$ : MM-LDL incubated in media only in the absence of any HDL preparation as a positive control; CTR PON: $125 \mu \mathrm{g} / \mathrm{ml} \mathrm{MM-}$ $\mathrm{LDL}+10 \mu \mathrm{g}$ unincubated, starting PON. An asterisk (*) represents significantly different values from CTR PON, $p<0.03$. Data are means \pm SEM for three individual experiments

\section{Discussion}

Because HDL is a powerful predictor of cardiovascular risk in general [2], and patients with Type II diabetes have an accelerated incidence of atherosclerosis [38], glycation of HDL could be an important factor in the development of diabetic macrovascular disease. In this study, we explored how hyperglycaemia can influence the anti-atherogenic properties of HDL through formation of glycated HDL. We acknowledge that $25 \mathrm{mmol} / \mathrm{l}$ glucose represents extreme hyperglycaemia that would be encountered in diabetes. In more severe cases of diabetes, it is, however, conceivable that glycation/glycoxidation of HDL proteins within 1 week alters HDL function.

Under aerobic conditions, glycation and oxidation interact to form glycoxidation, or advanced glycation end products (AGEs), on protein. Advanced glycation end products could arise from autoxidation of either fructoselysine or of glucose itself [39-41]. One of the originally described and chemically defined AGEs is CML [42]. It is important to note that our studies were conducted in the presence of air, i.e. under oxidative conditions, so that we did not attempt to distinguish the effects of glycation reactions independent of glycoxidation reactions. We have, however, shown the formation of CML under these conditions, which indicates that advanced glycation reactions have occurred. We also have to consider the possibility that the CML formed in HDL is a biomarker of protein modification by advanced glycation re- actions but that because of its low absolute concentration, CML itself is not likely to be responsible for the alterations observed in HDL function.

Both glycated HDL and HDL incubated in PBS in the absence of glucose became larger in size over the week-long incubation. Incubation in glucose caused a statistically significant increase in oxidised lipids in the HDL preparations, although in this study we could not determine if the AGEs formed in such glycated HDL were derived from these oxidised lipids. There was also some formation of TBARS in the HDL preparations incubated in the absence of glucose, suggesting oxidation of the HDL during the incubation period.

Patients with Type II diabetes have reduced plasma concentrations of $\mathrm{HDL}_{2}$ and increased concentrations of $\mathrm{HDL}_{3}$ [13]. Hepatic lipase activity reduces phospholipid and triglyceride concentrations in $\mathrm{HDL}_{2}$ and increases phospholipid concentrations in $\mathrm{HDL}_{3}$. The composition of HDL has been shown to affect its ability to react with hepatic lipase $[10,11]$. A direct correlation between plasma $\mathrm{HDL}_{3}$ concentrations and hepatic lipase activity has been shown in diabetic patients [12-14]. Our studies provide evidence that HDL with altered protein and lipid adducts formed by glycation/glycoxidation have an enhanced ability to interact with hepatic lipase (Fig. 3).

Several studies have shown the importance of HDL in prevention of the early steps of atherogenesis, such as in monocyte adhesion to endothelium. Plasma HDL has been shown to prevent monocyte adhesion to endothelial cells in response to MMLDL in vitro [3]. One mechanism by which HDL can prevent monocyte:endothelial interactions is through sequestration and destruction of oxidised lipids in MM-LDL through the action of the HDL-associated enzyme, PON [5, 27]. After 1 week of incubation in glucose, HDL showed, however, a reduced ability to prevent monocyte adhesion to endothelial cells in response to oxidised lipids within MM-LDL, suggesting that PON activity had been reduced by glycation.

To examine such effects of glycation/glycoxidation on PON activity, we did experiments in which we glycated purified PON protein. We found that glycation of purified $\mathrm{PON}$ protein caused a reduction in its activity by $40 \%$. Paraoxonase activity was only slightly reduced $(18 \%)$ in PON protein incubated in the absence of glucose. In HDL incubated in the absence of glucose (PBS HDL), we found, however, that PON activity was statistically significantly reduced by $30 \%$ (data not shown). The mechanisms for this are not known but could be related to the presence of other oxidised lipids and proteins present in HDL, which could accelerate the increase in the oxidation of PON, leading to a rapid decrease in PON activity. Glycation of either PON or HDL resulted, however, in a pronounced reduction in PON activity, which was greater than that observed in the absence 
of glycation. It is possible that glycation of PON protein causes a change in the protein that results in a greater reduction in PON activity than does oxidation. The ability of PON to inhibit oxidation of LDL has been shown to require the cysteine residue at amino acid position 283 [43]. Blockage of this cysteine residue resulted in pronounced inhibition of PON activity [43]. We observed a direct correlation with the amount of PON activity and the ability of PON and HDL to inhibit monocyte adherence to endothelial cells. We found a $40 \%$ decrease in PON activity in a group of Type II diabetic subjects with CAD compared with a group of non-diabetic subjects with CAD. Decreased PON in patients with Type II diabetes and CAD have also been found [44, 45]. Polymorphisms within the $P O N$ gene that are prevalent in Type II diabetic patients with CAD have been reported $[7,46]$. These PON polymorphisms result in lower PON activity and are considered to be independent risk factors for CHD in Type II diabetic patients. We did not identify the presence of these polymorphisms in patients in the current study.

We have shown that glycation/glycoxidation of HDL decreases several key functions of the particle, rendering the HDL more pro-atherogenic. These activities include HDL association with hepatic lipase and the antioxidant properties of HDL mediated primarily through PON.

Acknowledgements. We are grateful to Dr. B. N. LaDu for providing us with purified PON protein and to Dr. L. W. Castellani and S. Charugundla for help in the NEFA determinations. We also thank Drs. J. A. Berliner and A. J. Lusis for critical review of the manuscript. This work was supported by National Institutes of Health grants PO1-HL55 782 (S. R. Thorpe and M.-X. Fu), DK19971 (S. R. Thorpe), and PO1-HL55 798 (C. C. Hedrick).

\section{References}

1. Karathanasis SK (1992) Lipoprotein metabolism: highdensity lipoprotein. In: Lusis AJ, Rotter JI, Sparkes RS (eds) Monographs in Human Genetics: Molecular Genetics of Coronary Artery Disease. Karger, Basel, pp 140-171

2. Miller NE (1987) Associations of high-density lipoprotein subclasses and apolipoproteins with ischemic heart disease and coronary atherosclerosis. Am Heart J 113: 589-597

3. Navab M, Imes SS, Hough GP et al. (1991) Monocyte transmigration induced by modification of LDL in cocultures of human aortic endothelial cells is due to induction of MCP-1 synthesis and is abolished by HDL. J Clin Invest 88: 2039-2046

4. Mackness MI, Arrol S, Durrington PN (1991) Paraoxonase prevents accumulation of lipoperoxides in low density lipoprotein. FEBS Lett 286: 152-154

5. Watson AD, Berliner JA, Hama SY et al. (1995) Protective effect of high-density lipoprotein associated PON. Inhibition of the biological activity of minimally oxidized low density lipoprotein. J Clin Invest 96: 2882-2891

6. Adkins S, Gan KN, Mody M, La Du BN (1993) Molecular basis for the polymorphic forms of human serum paraoxo- nase: glutamine or arginine at position 191, for the respective A or B allozymes. Am J Hum Genet 52: 598-608

7. Ruiz J, Blanche H, James RW et al. (1995) Gln-Arg192 polymorphism of paraoxonase and coronary heart disease in Type 2 diabetes. Lancet 346: 869-872

8. Rao SN, Cortese C, Miller NE, Levy Y, Lewis B (1982) Effects of heparin infusion on plasma lipoproteins in subjects with lipoprotein lipase deficiency. Evidence for a role of hepatic endothelial lipase in the metabolism of HDL subfractions in man. FEBS Lett 150: 255-259

9. Brinton EA, Eisenberg S, Breslow JL (1994) Human HDL cholesterol levels are determined by apoAI fractional catabolic rate, which correlates inversely with estimates of HDL particle size. Effects of gender, hepatic and lipoprotein lipases, triglyceride and insulin levels, and body fat distribution. Arterioscler Thromb 14: 707-720

10. Mowri H-O, Patsch W, Smith LC, Gotto AM Jr, Patsch JR (1992) Different reactivities of $\mathrm{HDL}_{2}$ subfraction with hepatic lipase. J Lipid Res 33: 1269-1272

11. Mowri H-O, Patsch JR, Gotto AM Jr, Patsch W (1996) Apolipoprotein AII influences the substrate properties of human $\mathrm{HDL}_{2}$ and $\mathrm{HDL}_{3}$ for hepatic lipase. Arterioscler Thromb Vasc Biol 16: 755-762

12. Riemens S, van Tol A, Sluiter W, Dullaart R (1998) Elevated plasma cholesteryl ester transfer in NIDDM: relationships with apoB-containing lipoproteins and phospholipid transfer protein. Atherosclerosis 140: 71-79

13. Syvanne M, Ahola M, Lahdenpera S et al. (1995) High density lipoprotein subfractions in non-insulin dependent diabetes mellitus and coronary artery disease. J Lipid Res 36: 573-582

14. Thulaseedharan N, Augusti KT (1995) Risk factors for coronary heart disease in noninsulin-dependent diabetes. Indian Heart J 47: 471-476

15. Ruderman NB, Williamson, JR, Brownlee M (1992) Glucose and diabetic vascular disease. FASEB J 6: 2905-2914

16. Rabini RA, Fumelli P, Galassi R et al. (1994) Increased susceptibility to lipid oxidation of low-density lipoproteins and erythrocyte membranes from diabetic patients. Metabolism 43: 1470-1474

17. Lyons TJ, Jenkins AJ (1997) Glycation, oxidation, and lipidoxidation in the development of the complications of diabetes: a carbonyl stress hypothesis. Diabetes Rev 5: 365-391

18. Kim JA, Berliner JA, Natarajan RD, Nadler JL (1994) Evidence that glucose increases monocyte binding to human aortic endothelial cells. Diabetes 43: 1103-1107

19. Sell DR, Lapolla A, Odetti P, Fogarty J, Monnier VM (1992) Pentosidine formation in skin correlates with severity of complications in individuals with long standing IDDM. Diabetes 41: 1286-1292

20. Beisswenger PJ, Moore LL, Brinck-Johnsen T, Curphey TJ (1993) Increased collagen-linked pentosidine levels and advanced glycation endproducts in early diabetic nephropathy. J Clin Invest 92: 212-217

21. McCance DR, Dyer DG, Dunn JA et al. (1993) Maillard reaction products and their relation to complications in insulin dependent diabetes mellitus. J Clin Invest 92: $2470-2478$

22. Cohen MP (1986) Diabetes and protein glycosylation: measurement and biological relevance. Springer, Berlin Heidelberg New York

23. Duell PB, Oram JF, Bierman EL (1991) Nonenzymatic glycosylation of HDL and impaired HDL-receptor mediated cholesterol efflux. Diabetes 40: 377-384

24. O K, Hill JS, Pritchard PH (1995) Role of n-linked glycosylation of LCAT in lipoprotein substrate specificity. Biochem Biophys Acta 1254: 193-197 
25. Fievet C, Igau B, Bresson R, Drouin P, Fruchart JC (1995) Non-enzymatic glycation of apolipoprotein AI and its functional consequences. Diabetes Metab 21: 95-98

26. Burstein M, Scholnick HR, Morfin R (1970) Rapid method for isolation of lipoproteins from human serum by precipitation with polyanions. J Lipid Res 11: 583-595

27. Navab M, Hama-Levy S, Van Lenten BJ et al. (1997) Mildly oxidized LDL induces an increased apolipoprotein $\mathrm{J} /$ paraoxonase ratio. J Clin Invest 99: 2005-2019

28. Hedrick CC, Castellani LW, Warden CH, Puppione DL, Lusis AJ (1993) Influence of mouse apolipoprotein AII on plasma lipoproteins in transgenic mice. J Biol Chem 268: 20676-20682

29. Knecht KJ, Dunn JA, McFarland KF et al. (1991) Oxidative degradation of glycated proteins: effects of diabetes and aging on $\mathrm{N}$-carboxymethyl)lysine levels in human urine. Diabetes 40: 190-196

30. Zhang A, Vertommen J, Van Gaal L, De Leeuw I (1994) A rapid and simple method for measuring the susceptibility of low-density lipoprotein and very low density lipoprotein to copper-catalyzed oxidation. Clin Chim Acta 227: 159-173

31. McDowell IF, McEneny J, Trimble ER (1995) A rapid method for measurement of the susceptibility to oxidation of low-density lipoprotein. Ann Clin Biochem 32: 167-174

32. Warden CH, Hedrick CC, Qiao JH, Castellani LW, Lusis AJ (1993) Atherosclerosis in transgenic mice overexpressing apolipoprotein AII. Science 261: 469-472

33. Watson AD, Leitinger N, Navab M et al. (1997) Structural identification by mass spectrometry of oxidized phospholipids in minimally oxidized low density lipoprotein that induce monocyte/endothelial interactions and evidence for their presence in vivo. J Biol Chem 272: 13597-13607

34. Pawlowski NA, Abraham EL, Pointer S, Scott WA, Cohen ZA (1985) Human monocyte:endothelial cell interaction in vitro. Proc Natl Acad Sci USA 82: 8208-8212

35. Fogelman AM, Sykes K, Van Lenten BJ, Territo MC, Berliner JA (1988) Modification of the Recalde method for the isolation of human monocytes. J Lipid Res 29: 1243-1247

36. Fu M-X, Requena JR, Jenkins AJ, Lyons TJ, Baynes JW, Thorpe SR (1996) The advanced glycation endproduct, $\mathrm{N}-{ }^{e}$ (carboxymethyl)lysine is a product of both lipid peroxi- dation and glycoxidation reactions. J Biol Chem 271: 9982-9986

37. Cushing SD, Berliner JA, Valente AJ et al. (1990) Minimally modified low density lipoprotein induces monocyte chemotactic protein-1 in human endothelial cells and smooth muscle cells. Proc Natl Acad Sci USA 87: 5134-5138

38. Tkac I, Kimball BP, Lewis G, Uffleman K, Steiner G (1997) The severity of coronary atherosclerosis in Type 2 diabetes mellitus is related to the number of circulating triglyceriderich lipoprotein particles. Arterioscler Thromb Vasc Biol 17: $3633-3638$

39. Lyons TJ (1995) Glycation, oxidation, and glycoxidation reactions in the development of diabetic complications. Contrib Nephrol 112: 1-10

40. Baynes JW (1991) Role of oxidative stress in the development of diabetic complications. Diabetes 40: 405-412

41. Wells-Knecht MC, Thorpe SR, Baynes JW (1995) Pathways of formation of glycoxidation products during glycation of collagen. Biochemistry 34: 15134-15141

42. Reddy S, Bichler J, Wells-Knecht KJ, Thorpe SR, Baynes JW (1995) N-(carboxymethyl)lysine is a dominant advanced glycation end product (AGE) antigen in tissue proteins. Biochemistry 34: 10872-10878

43. Aviram M, Billecke S, Sorenson R et al. (1998) Paraoxonase active site required for protection against LDL oxidation involves its free sulfhydryl group and is different from that required for its arylesterase/paraoxonase activities: selective action of human paraoxonase allozymes $\mathrm{Q}$ and $\mathrm{R}$. Arterioscler Thromb Vasc Biol 18: 1617-1624

44. Mackness B, Mackness MI, Arrol S et al. (1998) Serum paraoxonase (PON1) 55 and 192 polymorphism and paraoxonase activity and concentration in non-insulin dependent diabetes mellitus. Atherosclerosis 139: 341-349

45. Pfohl M, Koch M, Enderle MD et al. (1999) Paraoxonase $192 \mathrm{Gln} / \mathrm{Arg}$ gene polymorphism, coronary artery disease, and myocardial infarction in type 2 diabetes. Diabetes 48 : 623-627

46. Garin MC, James RW, Dussoix P et al. (1997) Paraoxonase polymorphism Met-Leu54 is associated with modified serum concentrations of the enzyme. A possible link between the paraoxonase gene and increased risk of cardiovascular disease in diabetes. J Clin Invest 99: 62-66 